Teosofia: Indonesian Journal of Islamic Mysticism, Vol. 10, No. 2, 2021, pp. 229-248

e-ISSN: 2540-8186; p-ISSN: 2302-8017

DOI: $10.21580 /$ tos.v10i2.8629

\title{
PHYSICAL AND SPIRITUAL DIMENSIONS OF HAPPINESS IN THE THOUGHT OF AL-FĀRĀBĪ AND IBN SİNĀ
}

\author{
Mukhammad Zamzami \\ Faculty of Ushuluddin and Philosophy, \\ Sunan Ampel State Islamic University Surabaya, Indonesia \\ Corresponding author: m.zamzami@uinsby.ac.id \\ Abdullah HosseiniEskandian \\ Faculty of Theology, University of Tabriz, Iran \\ hosseinieskandianabdullah@gmail.com \\ Hossein Gholizadeh \\ Faculty of Theology, Farhangian University, Iran \\ m.pur61@gmail.com \\ Mohammad Moradi Shariati \\ Faculty of Theology, Farhangian University, Iran \\ moradi19888@gmail.com \\ Muktafi \\ Faculty of Ushuluddin and Philosophy, \\ Sunan Ampel State Islamic University Surabaya, Indonesia \\ muktafi.sahal@uinsby.ac.id \\ Abd A'la \\ Faculty of Adab and Humanities, \\ Sunan Ampel State Islamic University Surabaya, Indonesia \\ abdalabs@gmail.com
}

Article History: Received: 20 July 2021; Accepted: 15 December 2021; Published: 27 December 2021

\begin{abstract}
:
The most important goal in human life is to achieve happiness, and because people are subject to certain ideas and beliefs and have a different system of thought, it has led to different interpretations of happiness. If the Sufis interpret happiness around the orbit of inner happiness in the soul, not related to material achievements such as money, children, prestige, offspring, and others, then this is different from the interpretation of the happiness of two Muslim philosophers, Ibn Sìnā and al-Fā rābì. In this article, with a descriptive-analytical method and using library resources, we first try to study the lexicon of the word happiness and the views of other thinkers in this regard, in the following, what are happiness, the levels of happiness, and the classification of happiness in the intellectual system of Ibn Sìnā and al-Fārābì. Happiness in Ibn Sinnā and al-Fārābì's thought is the same concern of human perfectionism from the beginning of creation, and this has caused these two philosophers to discuss this in their different works, and both philosophers do not know human happiness as anything other than reaching God and His pleasure.
\end{abstract}

Keywords: Eternal happiness; Happiness; al-Fārā bù; Ibn Sìnā; Nearness to God 


\section{A. Introduction}

7 he issue of happiness is one of the fundamental and long-lasting issues that has always been discussed in different eras by philosophers, writers, narrators, theologians, etc., and since the intellectual system of each of these sciences is different from the other, it has caused express different interpretations of this issue. From the point of view of philosophers, happiness is achieved by increasing knowledge, and from the point of view of Islamic philosophers, in addition to knowledge, this also requires virtue and obedience to God's commands. ${ }^{1}$ Islamic thinkers believe that happiness should be achieved in this world and the hereafter, and just to consider the world worthless in the direction of happiness is against the will of God, and man in the world must strive for his own happiness in order to reach the happiness of the hereafter, which is in fact true happiness. ${ }^{2}$ The differences that exist in different schools about happiness are due to differences in worldviews, and this has led to different interpretations of happiness, and it is clear that the school or a person who does not believe in the hereafter will not believe in happiness in that world and will do his best for the fleeting prosperity of this world. However, true happiness will be achieved in the hereafter, and the happiness of this world is nothing but the pleasure of God Almighty and taking a step towards His commands.

Al-Fārābī and Ibn Sīnā, great Islamic philosophers, have paid special attention to the issue of happiness in their works and have given detailed opinions on this subject and have called it absolute goodness and absolute perfection. According to Ibn Sīnā, in order to achieve happiness, a person must either increase his rational power to a higher level of knowledge and gain more awareness of himself and his Lord, and he must promote practical intellect by carrying out divine commands and avoiding prohibitions. ${ }^{3}$ According to al-Fārābī, happiness is in the light of increasing knowledge and acquiring virtue, and it is the ultimate happiness that is called true happiness..$^{45}$

However, in the article "Analysis of the Meaning of Happiness from al-Fārābī's Point of View", written by Einullah Khademi, also the article "Happiness according to Ibn Sīnā”, written by Ainullah Khademi, "Konsep Kebahagiaan dalam Perspetif al-

1 Seyyed Hossein Nasr, "Happiness and the Attainment of Happiness: An Islamic Perspective," Journal of Law and Religion 29, no. 1 (February 19, 2014): 76-91, https://doi.org/10.1017/jlr.2013.18.

2 Vincent J. Cornell, "Applying the Lessons: Ideals versus Realities of Happiness from Medieval Islam to the "Founding Fathers"," Journal of Law and Religion 29, no. 1 (February 19, 2014): 92-108, https://doi.org/10.1017/jlr.2013.7.

3 Ibn Sīnā, Aḥwāl Al-Nafs: Risālah Fi Al-Nafs Wa Baqāuhā Wa Ma Āduhā (Beirut: Dār Iḥā' alKutub al-'Arabiyyah, 1952), 45, 55, 139.

4 Abū Naṣr Al-Fārābī, Kitāb Tahṣīl Al-Sa ādah, Tahquiqq: Ja 'far 'Aた Yāsin (Beirut: Dār al-Andalus li al-Ṭibā'ah wa al-Nashr wa al-Tawzī', 1983), 3, 6, 19.

5 Said Jabbali, "Happiness in the Thought of Al-Farabi: Theory and Practice," Tabayyun 7, no. 25 (2018): 71-73, https://tabayyun.dohainstitute.org/en/issue025/Pages/art04.aspx. 
Farabi" written by Endrika Widdia Putri, ${ }^{6}$ the axes of this article have been addressed to some extent, but firstly, it has not been specifically examined for the concept of happiness and its relationship with other concepts such as justice, virtue, goodness, etc. has been explained, while it was necessary to pay special attention to the concept of happiness and its hierarchy, classification and meaning should be stated. Secondly, lexically and syntactically, the word happiness has not been addressed, while it is necessary to express its meaning and concept before beginning any discussion and also to use the views of other thinkers in this regard. Thirdly, no work has been written so far that examines and compares the views of Ibn Sīnā and al-Fārābī on happiness, and this has necessitated the presentation of a comprehensive study in this regard. In this article, an attempt is made to answer these questions by referring to the various works of Ibn Sīnā and al-Fārābī and other authoritative sources.

This is different from the approach taken by the Sufis in understanding the meaning of happiness. For the Sufis, happiness cannot be achieved easily, because happiness has a ladder to climb so that they can find true happiness. The spiritual journey of the Sufis to find "true happiness" must be passed through a layered scheme of maqāmāt and ahwāl. Sometimes this journey to happiness requires a murshid or a pious person to show the good and right path. ${ }^{7}$ At least, the Sufis also go through three important stages to get this happiness. Takhali, tahalh, and tajall are the three groups of Sufism doctrines that are able to deliver Sufis. Each stage requires some kind of patience, perseverance, and great effort to gain God's approval and enjoy divine encounters and revelations. ${ }^{8}$

By using library research, this article specifically analyzes the meaning of happiness from the point of view of al-Fārābī and Ibn Sīnā and what the differences and similarities between al-Fārābī and Ibn Sīnā's views on happiness are. These two philosophers are considered essential to compare because their philosophical foundations both follow the Aristotelian school of thought, namely followers of Aristotle's philosophical teachings. However, the philosophers, whether Muslim philosophers or medieval philosophers in the West, who followed Aristotle's philosophy were not entirely uniform in their thinking.

\section{B. Happiness from the Point of View of Other Thinkers}

The word happiness, which is called Eudamona in Latin, means the ultimate goodness, the ultimate goal, and goodness in affairs. ${ }^{9}$ The word happiness basically

6 Endrika Widdia Putri, “Konsep Kebahagiaan Dalam Perspektif Al-Farabi," THAQAFIYYAT: Jurnal Bahasa, Peradaban Dan Informasi Islam 19, no. 1 (2018): 95-111, http://ejournal.uinsuka.ac.id/adab/thaqafiyyat/article/view/1321.

7 Nasr, "Happiness and the Attainment of Happiness: An Islamic Perspective."

8 Istifaiyah Istifaiyah, “التّخلّق باخلاق الله عند عبد الكريم القشيري," Teosofia: Indonesian Journal of Islamic Mysticism 4, no. 2 (October 16, 2015): 123-36, https://doi.org/10.21580/tos.v4i2.1719.

9 Ahmad Ibn Faris, Dictionary of Language Comparisons (Qom: Islamic Media Library, 1978), 75.

Teosofia: Indonesian Journal of Islamic Mysticism, Vol. 10, No. 2, 2021 
means goodness and is the opposite of misfortune. So, happiness means goodness in affairs. ${ }^{10}$ Happiness also means goodness and the opposite of evil, and happiness is against cruelty, as it is said, the day of happiness and the day of evil. Khalil Ibn Ahmad Farahidi has also expressed the word happiness in the sense of good and anti-evil. ${ }^{11}$ "Alī al-Fayyūmī has expressed happiness in the sense of effort and difficulty in the path of religion and the world, and perhaps this meaning is because he does not consider happiness to belong only to the hereafter, but also from his point of view to the world. ${ }^{12}$ In dictionary books as well as encyclopedias, meanings such as good fortune, bless, help and assistance, striving for perfection, perfectionism, good faith, and goodness are stated for the word happiness, but in sum, all these meanings imply the attainment of a kind of true perfection by God which should be the main goal in human life.

On the other hand, according to different scientific fields, thinkers have expressed different views and definitions of the concept of happiness. On the other hand, religious thinkers of different religions have expressed true happiness in defending their religion by following the beliefs and customs of their religion. In expressing what happiness is, mystics associate it with God, and philosophers associate it with the Tenth Intellect.

The desired happiness of all human beings is the ultimate goal of all their rational deeds, and for this reason, it is the only good thing that leads to human happiness and perfection. ${ }^{13}$ Socrates considers happiness to be the carnal state resulting from the combination of virtue and pleasure. ${ }^{14}$ Plato also described happiness as a mixture of intellectual knowledge or physical and sensory pleasure. Herodotus also considered happiness to be the result of human actions. ${ }^{1516}$ Aristotle philosophers have emphasized that human happiness is achieved by completing theoretical and practical powers. According to them, philosophy is a means to achieve this happiness. In fact, the goal of man in life is to achieve happiness, and happiness is achieved only through

10 Jamāl al-Dīn Abī al-Faḍl Muhammad b. Mukarram b. Manẓūr al-Anșārī al-'Ifrīqī Al-Miṣrī, Lisān Al-'Arab, vol. 3 (Beirut: Dar al-Fikr, 1988), 57.

11 Khalil Ibn Ahmad Farahidi, Al- 'Ayn (Qom: Hijrat Publications, 1983), 21.

12 Aḥmad b. Muhammad b. 'Alī al-Fayyūmī Al-Muqrī, Al-Misbāḥ Al-Munīr Fì Ghañ̄b Al-Sharḥ AlKabìr, vol. 1 (Qom: al-Dar al-Hejrat Publications, 1988), 276.

13 Gregory Vlastos, "Happiness and Virtue in Socrates' Moral Theory," Proceedings of the Cambridge Philological Society 30 (February 28, 1984): 181-213, https://doi.org/10.1017/S0068673500004685.

14 George Klosko, "Socrates on Goods and Happiness," History of Philosophy Quarterly 3, no. 4 (1987): 251-64, https://www.jstor.org/stable/27743814.

15 Darrin M. McMahon, Happiness: A History (New York: Atlantic Monthly Press, 2007), 1.

16 Jonathan Culp, “Who's Happy in Plato's Republic?," Polis 31, no. 2 (August 15, 2014): 288-312, https://doi.org/10.1163/20512996-12340018. 
science because science is light and ignorance of darkness and true knowledge also leads to good deeds. ${ }^{1718}$

Happiness means perfection of both physical and spiritual dimensions, and the perfection of the soul or body alone does not lead to happiness, but since happiness or physical goodness do not directly interfere with achieving happiness, they are not part of happiness. ${ }^{19}$ Happiness is that each person achieves the perfection that God Almighty has placed in his nature and essence through his actions, voluntary movements, and voluntary actions; that is, the kind of perfection that is specific to human beings. ${ }^{20}$

According to Muslim thinkers such as Mullā Șadrā, happiness is anything in reaching the perfection of what is the highest level of intellectual happiness. ${ }^{2122}$ As for Fakhr al-Dīn al-Rāzī considered a happy person is a person of reward in the hereafter. On the other hand, miserable is the one who is an eagle and a punisher. ${ }^{23}$ As for Muhammad Husayn al-Ṭabāțabā'î in the definition of happiness states: "The happiness of everything is to reach the good of its existence in order to realize its perfection and thus enjoy it, and happiness in man, which is a being composed of soul and body, is to achieve physical and spiritual good and enjoy it". 24

According to the Sufis, the meaning of happiness revolves around the orbit of inner happiness in the soul, not related to material achievements such as money, children, prestige, offspring, and others. In Miftāh Dār al-Sa'ādah, Ibn al-Qayyim describes the world as a place of abode of anxiety and sorrow, and its inhabitants created from good and evil, and that Allah sent down to them the world as a dwelling place of faith in the unseen through which only pleasure faith is earned. The world is only a manifestation of the misery that happened to Prophet Adam when he disobeyed

17 Gary M. Gurtler, "The Activity of Happiness in Aristotle's Ethics," The Review of Metaphysics 56, no. 4 (2003): 801-34, https://www.jstor.org/stable/20131900.

18 Stephen S. Bush, "Divine and Human Happiness in 'Nicomachean Ethics," The Philosophical Review 117, no. 1 (2008): 49-75, https://www.jstor.org/stable/41441846.

19 Nașīr al-Dīn Al-Ṭūsī, Nasirean Ethics (Tehran: Islamic Theological Publications, 1987), 49.

20 Ibrahim Yaqoubi, "Happiness from the Viewpoint of Ibn Sīnā and Allameh Tabatabai," University Scientific Quarterly 10, no. 1 (2007): 221.

21 Muhammad b. Ibrāhīm Mullā Ṣadrā, Sharḥ Ușūl Al-Kāfi, trans. Mohammad Khajavi (Tehran: Institute of Humanities and Cultural Studies, 2004), 301-2.

22 Mohammad Reza Shamshiri and Zahra Allafchian, “A Comparative Study of 'Happiness' in View of Mulla Sadra and Spinoza," Biannual Scientific Journal Sadrā'i Wisdom 8, no. 2 (2020): 177-91, http://pms.journals.pnu.ac.ir/article_5013_en.html.

23 Abū 'Abd Allah Muhammad b. 'Umar b. al-Ḥasan b. al-Ḥusayn al-Taymī Al-Rāzī, Mafãtīh AlGhayb, vol. 18 (Beirut: Dār al-Fikr, 1975), 62.

24 Muḥammad Ḥusayn Al-Ṭabāțabā‘ī, Al-Mizān Fi Tafs̄ir Al-Qur'ān, trans. Mohammad Baqer Mousavi Hamedani, vol. 11 (Tehran: Allameh Tabatabai Scientific and Intellectual Foundation (Golshan Press), 1988), 228. 
God Almighty. Allah promises mankind all kinds of happiness in the hereafter by avoiding Allah's prohibitions and following His commands. ${ }^{25}$

In the book of Kìmiyā' al-Sa âadah (The Chemistry of Happiness), Abū Hāmid alGhazālī describes the human problem; God made man composed of body and soul. Within each part, there are connected qualities that need to be fulfilled in order to achieve happiness like the happiness experienced by animals, demons, or angels. Because humans will return to God, what is dominant is the nature of angels, namely true happiness in knowing and getting closer to God. To be a perfect human being is to put your trust in Him alone and balance all the qualities so that no one trait is dominant over the other. ${ }^{26}$ As for in $I h y \bar{a}$ ' 'Ulūm al-Dìn, al-Ghazālī makes the true pleasure is happiness in the hereafter, and happiness other than that is a mistake or pseudo. He made the happiness of seeing the face of Allah and the happiness of the Hereafter in general what he sought for himself, and everything else was pursued to achieve this goal. ${ }^{27}$

Perhaps one of the most important terms denoting happiness according to Sufism is ma'rifah, mahabbah, riḍa, bast, and wajd, and other terms follow them and revolve around the same meaning.

Ma'rifah is self-knowledge through which only man gains knowledge of his Lord and the reality of this soul and its composition so that he knows how and where his happiness is. God and see the greatness of His creation in this world and in the soul itself. ${ }^{28}$ Mah $a b b a h$ ) is love for God Almighty and longing for Him so that only Allah is the Beloved, and love for creation comes from His love, and the lover becomes happy to obey His Beloved and is pleased with everything that He gives, even if it is trials and tribulations. ${ }^{29}$ As for rid̄ which is after love, it is related to the equal feeling of a servant no matter what happens to him, what happens to him is Allah's destiny which He wants for him and he with His approval is in eternal happiness where calamity, whatever it may be, it is from God, and God only wants good for us. ${ }^{30}$ The term of bast is a favor from Allah which He throws into the heart of a servant so that he becomes comfortable in mind, optimistic about the mercy of his Lord, and happy with the circumstances that Allah has created, and he does not care about any of the affairs of the world. ${ }^{31}$ As for wajd or wajad is a blessing from Allah which He sent down into the heart of a servant, but it is higher than simplicity and closest to Allah, and the

25 Ibn al-Qayyim Al-Jawzīyah, Miftāḥ Dār Al-Sa'ādah Wa Manshūr Wilāyat Al-'Ilm Wa Al-Irādah (Jeddah: Majma' al-Fiqh al-Islāmī, 2011), 48.

26 Abū Ḥāmid Al-Ghazālī, Kīmiyā Al-Sa'ā dah (Miṣr: Maṭba'at al-Sa'ādah, 1924), 25.

27 Abū Ḥāmid Al-Ghazālī, Ihyō̄ 'Ulūm Al-Dīn (Saudi Arabia: Dār al-Minhāj, 2013), 198.

28 'Abd al-Razzāq Al-Kāshānī, 'Abd Al-Razzāq Al-Kāshānī, Mu'jam Iṣtilāḥāt Al-Ṣūfiyah, Taḥqīq: 'Abd Al-'Āl Shāhīn (Cairo: Dār al-Mannār, 1992), 363-64.

29 Al-Kāshānī, 198.

30 Al-Kāshānī, 248.

31 Al-Kāshānī, 354. 
happiness that is obtained from it is even greater. So hatred happens to the servant by chance and it is one of the goodness of Allah, but based on the visible work of remembrance and maintenance of worship, and ecstasy is acquiring the sweetness of obedience. $^{32}$

Many terms revolve around the same meaning, which we cannot name, so we have listed the most important of them. The main idea that brings happiness to the Sufis is still the ascension that leads to Allah and is pleased with them, so that $\mathrm{He}$ implants into their hearts the kinds of happiness through Him, the Most Mighty, the Greatest.

As for happiness according to modern Western philosophers such as Augustine, he states that to be happy, one must learn wisdom, and it is necessary to know wisdom to know the truth. ${ }^{33}$ As for Thomas Aquinas, happiness is something that is inherently valuable and not for anything else, and this can only be achieved by knowing God and reflecting on him. ${ }^{3435}$

The important principle in defining happiness is its hierarchy, and this has led to different definitions of it, and each thinker has highlighted one of its aspects and levels in comparison with other levels. In fact, happiness is that we take a step in the path that God has specified and the prophets have enlightened it, and we obey the divine commands and avoid prohibitions so that we can achieve happiness both in this world and in the hereafter. In fact, true happiness is the satisfaction of God Almighty from His servants because His pleasure leads to salvation with which none of the things described as happiness can be compared.

\section{Happiness in al-Fārābī's Thought}

Al-Fārābī has given different definitions of happiness in his works, and this may be due to the fact that he has linked its definition with the subject of his work, just as when he speaks about the utopia, he considers the happiness of society, or when he discusses the soul separately, he expresses the happiness of each of the powers of the population. Al-Fārābī, like Plato, believes that the main goal of morality is to achieve happiness, because happiness is the last goal that a person strives to achieve and is the highest good, and the more one strives to achieve this good, the more complete his happiness will be. ${ }^{3637}$

32 Al-Kāshānī, 317.

33 Aurelius Augustine, The Confessions of Saint Augustine, trans. Edward Bouverie Pusey (London: Chatto \& Windows, 1921), 28.

34 Stephen Wang, “Aquinas on Human Happiness and the Natural Desire for God," New Blackfriars 88, no. 1015 (May 2007): 322-34, https://doi.org/10.1111/j.1741-2005.2006.00136.x.

35 Joseph Rickaby S.J., Joseph Rickaby S.J., Summa Contra Gentiles of Thomas Aquinas, Book 3 (London: Burns and Oates, 1905), 27.

36 Abū Nașr Al-Fārābī, Risālat Al-Tanbīh 'alā Sabīl Al-Sa 'Ādah, ed. Subhān Khalīfāt (Oman: alJāmi'ah al-Urduniyyah, 1987), 177. 
Al-Fārābì in the definition of happiness states: "Happiness is the transformation of the soul, and in the perfection of its existence to the extent that it does not need matter in its consistency, and this is required for the soul to be perfected to the extent that it becomes one of the beings different and free from matter" and then he once again in the definition of happiness states: "Happiness is something that is good and desirable, and it is not something that is absolutely or at a time when it is other than the desired time and the means of achieving something else, and beyond that, there is nothing else that is more desirable than it. Happiness is the goal that every human being desires and everyone strives to achieve it, and this is because happiness is a kind of perfection. Happiness is the greatest degree of goodness among all good deeds, and it is the most perfect goal among all the things that human beings strive for from the beginning because some things are only a means to an end". ${ }^{38}$

Happiness is the absolute good; all the things that are useful in achieving happiness are considered good, but their goodness is not inherent and pleasurable, but because of the benefit they have in achieving happiness, they are good, and all the things that prevent the attainment of happiness are absolutely evil. ${ }^{39}$

From al-Fārābī's point of view, happiness has characteristics such as being good and being the best of virtues, and in this regard, he states that happiness is absolutely good, and whatever is useful in achieving it is also good. Also, happiness is acquired and is not innate and is achieved by a person with the will and authority that God has given him. ${ }^{40}$ On the other hand, happiness is a multifaceted thing and has different degrees. Al-Fārābì states that the highest degree of happiness is not possible except for those who have true wisdom and also happiness has inherent desirability so we want happiness only because we do not want it for something else but for ourselves. He says in this regard that happiness is never asked for something else". ${ }^{41}$

Al-Fārābī states that it is natural for human beings to strive for happiness. The highest happiness and perfection are unattainable without the help of many people. Therefore, another knowledge is needed to examine the rational principles in the light of human necessities in coexistence; that is, human or political knowledge. Man is able to fulfill the natural desires of man as a civil animal that goes back to metaphysical thinking. This thinking involves accepting the first principle, God, and then human beings turn to the human science of politics and ask about the purpose of human existence, that is, the perfection that human beings must reach. He examines

37 Ja'far Āl Yãsin, Al-Fãrābì: Fỉ Ḥudūdih Wa Rusūmih (Beirut: Dār 'Ālam al-Kutub, 1985), 284.

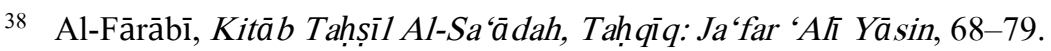

39 Abū Naṣr Al-Fārābī and 'Alī Būmalḥam, Al-Siyāsah Al-Madaniyyah (Beirut: Dār wa Maktabat alHilāl, 1996), 91.

40 Abū Nașr Al-Fārābī and Seyed Jafar Sajjadi, Arā' Ahl Al-Mađínah Al-Fäḍilah (Tehran: Tahoori Publications, 1991), 226.

41 Al-Fārābī and Sajjadi, 228. 
everything that helps mankind to achieve happiness, such as good deeds and virtues, and distinguishes them from deeds that hinder perfection, such as evil deeds. ${ }^{42}$

Al-Fārābì considers four things as the cause of happiness: theoretical virtues, intellectual virtues, moral virtues, and practical sciences. ${ }^{43}$ According to Him, the first condition of happiness is that a person imagines himself separate from the material body and considers himself to have a soul that can be close to God with his greatness, and the second condition is that he can achieve true happiness by gaining intellectual insights. From al-Fārābī's point of view, happiness is in fact the highest perfectionism, and happiness is inherently desirable in human beings, and he considers happiness to be closeness and reaching "active intellect". ${ }^{4}$

\section{1. Degrees of Happiness in al-Fārābī's Thought}

One of the fundamental questions about happiness is whether happiness is fixed or variable? If it is variable, what is its highest level? Although al-Fārābì did not answer the first question directly in his writings, from his answer to the second question, one can get acquainted with his view on the first question, because if someone tries to answer the second question, it means that he does not consider happiness as a fixed thing, but considers it as a minor thing. In his works, al-Fārābī has tried to answer this question: what is the highest level of happiness? He mentions the highest level of happiness as the happiness of the hereafter and in different works, he gives seemingly different answers to this fundamental question. ${ }^{45}$

From al-Fārābī's point of view, bliss is that man achieves nearness to God Almighty and rests next to Him so that he can find happiness and for this, it is necessary to develop all his latent talents and use his abilities to achieve this goal and in this way, he should practice, because from his point of view, by worshiping and practicing the soul to the divine deeds, a person provides the ground for strengthening his soul and achieving happiness. According to Him, in order to achieve true happiness, man must acquire higher knowledge about himself and the world of creation, and by increasing his knowledge and insight, he must acquire true wisdom and know his God as he deserves in order to achieve happiness.

Achieving the highest degree of happiness depends on the fact that man first identifies all the talents hidden in his being and acquires knowledge about them, and in the next step, to think about the ways and means to actualize these hidden talents. After being aware of these methods and tools, he should make every effort to implement his scientific findings in practice.

\footnotetext{
42 Erwin Isak Jakob Rosenthal, Political Thought in Medieval Islam: An Introductory Outline (Cambridge: Cambridge University Press, 2009), 121.

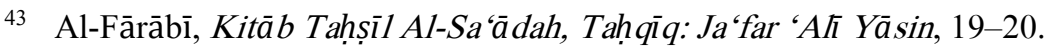

44 Al-Fārābī and Būmalham, Al-Siyā sah Al-Madaniyyah, 2, 92.

45 Abū Nașr Al-Fārābī, Fuṣūl Muntazi ‘Ah (Beirut: Dār al-Mashriq, 1993), 96.
} 
Happiness is a kind of intellect that is only in the power of theoretical rational power. Happiness, according to al-Fārābì, belongs to the perception of reason and rational power, and in essence, it is a rational thing that can be achieved with the help of reason. Of course, the highest human happiness is lower than the lowest stage of metaphysical intellects. Al-Fārābī says that happiness is that the soul reaches a level in its perfection of existence that does not need matter in its consistency and this means that it becomes one of the beings free from the body and one of the jewels of the various beings, and always remains in this state unless his rank is lower than that of the active intellect.

\section{2. Classification of Happiness from al-Fārābī's Point of View}

In a special interpretation of perfection, al-Fārābī considers a person to have two perfections; the hereafter happiness is the second perfection of man, the achievement of which depends on the first perfection, i.e., perfection in the world. ${ }^{46}$ According to him, the first perfection is achieved when man worships God. Worshiping God in the language of philosophy is the performance of all human virtues, which also depends on having those virtues. In other words, human perfection in this world is to be adorned with practical wisdom, which also depends on having theoretical wisdom. ${ }^{47}$

Al-Fārābī considers happiness to be of two types; true happiness and doubtful happiness. True happiness means happiness that is desirable in itself and is sought for its essence and not for the attainment of other goals. This happiness is the great happiness that will be achieved in the hereafter, but doubtful happiness includes things such as pleasure, wealth, status, etc., and these things are not happiness, but charities that are used to achieve happiness. ${ }^{48}$ From al-Fārābī's point of view, real happiness is not possible in this world. In this regard, he states:

"Happiness is the attainment of perfection. The first perfection of man is the
attainment of the first intellects, and these intellects are implanted in man in order
for man to use it in order to attain his recent perfection. Therefore, happiness is
the becoming and transfer of the soul in its perfection of existence to the extent
that it did not need matter in the perfection of existence, and this was to be
perfected to the extent that it became one of the beings deprived of matter". ${ }^{9}$

Of course, it is clear from al-Fārābī's other works that the impartation of the first intellects is the starting point of the movement of intellectual evolution and has the status of a means and is not considered a great perfection in itself. The final stage of

46 Abū Nașr Al-Fārābī, Al-Millah Wa Al-Nuṣuṣ Al-Ukhrā (Beirut: Dār al-Mashriq, 2002), 145-46.

47 Al-Fārābī, Kitāb Tahṣīl Al-Sa'ādah, Tahqūq: Ja 'far 'Aī Yāsin, 49-69; Shajari Morteza, "Happiness and Its Relationship with Knowledge and Worship from Ibn Sīnā's Point of View," Journal of $\begin{array}{llllll}\text { Philosophical } & \text { Research } & \text { 4, no. } & 8 & \text { (2010): } & \text { 59-91, }\end{array}$ https://www.sid.ir/en/journal/ViewPaper.aspx?id=389630.

48 Al-Fārābī, Al-Millah Wa Al-Nușūṣ Al-Ukhrā, 52.

49 Al-Fārābī and Sajjadi, Arā' Ahl Al-Madìnah Al-Fāḍilah, 185-86. 
this happiness, which is exactly in line with the course of intellectual development, is the separation from matter. Between these two stages, there is the stage of formation of the actual intellect and the used intellect, which again, as it turns out, has the stat us of a means and a way to connect to the active intellect, which itself is higher happiness. ${ }^{50}$

According to al-Fārābī, in order to achieve true happiness, man must know what happiness is and make it the end of his life and try to know the factors and industries that lead him to happiness. But because human beings are different from each other in terms of nature, then every human being is naturally not able to know happiness and its factors and reaches doubtful happiness..$^{51}$

Therefore, from al-Fārābī's point of view, all material things that are suspicious and not worthy of reliance should be activated as a means to achieve true happiness and intellect. According to Him, true happiness is achieved if we first improve our knowledge about it and know the happiness that deserves to be targeted, and this happiness should not be other than reaching God, because other than that, all other things are suspicious.

\section{Happiness in Ibn Sīnā's Thought}

Ibn Sīnā in his various works has expressed the meaning of happiness and blissful life and considers happiness as the most important goal of human life that should be devoted all its efforts to achieve it. He uses the concept of perfection to express what happiness is and states: "Happiness is the attainment of perfection". His meaning of perfection is the ultimate goal that every being can reach, and according to Ibn Sinnā, the desire to go to the ultimate goal in the existence of any being has been deposited. ${ }^{52}$

Ibn Sinā believes that every creature wants pleasure and therefore in the discussion of happiness, he also expresses the subject of pleasure and discusses its types; pleasure is in two parts, sensory pleasure, and intellectual pleasure. Sensory pleasure itself is in two parts; outward sensory pleasure is like eating and inward sensory pleasure is like desire and hope. The common people mistakenly think that the strongest pleasure is a sensory pleasure and achieving it leads to happiness, but Ibn Sina states that the weakest type of pleasure is a sensory pleasure, and the strongest type is an intellectual pleasure because the strongest pleasure is a pleasure whose perception is strong. ${ }^{53}$ In the definition of happiness, Ibn Sīnā says:

50 Al-Fārābī and Būmalḥam, Al-Siyāsah Al-Madaniyyah, 92; Hassan Majidi, "Happiness in The Thought of Farabi And S.T. Aquinas," Bi-Quarterly Journal of Political Science 9, no. 2 (2013): 95114, https://doi.org/10.30497/pk.2014.1694.

51 Al-Fārābī and Sajjadi, Arā’ Ahl Al-Madìnah Al-Fāḍilah, 119.

52 Ibn Sīnā, Treatise on Happiness (Qom: Bidar, 1974), 263.

53 Ibn Sīnā, Al-Ishārāt Wa Al-Tanbīhāt, ed. Sulaymān Dunyā, vol. 3 (Tehran: Book Publishing Office, 1977), 334. 
"Happiness is the total cessation of the consideration of the senses, the limitation of the view to the glory of the Almighty and the rational study of it. Due to this consideration, a form of the whole universe is reflected in the narrator's soul and it sees the soul of the whole universe while observing the essence of God rationally". 54

Ibn Sīnā believes that the one who acquires knowledge will attain certainty, and the one who attains certainty will find the path of happiness and go through it and undoubtedly reach its destination. This is the state of a person who has insight into religion and adheres to wisdom. ${ }^{55}$ In describing happiness, Ibn Sinna considers it as the perfection of every being, and in the case of man, he introduces not only the happiness of the human soul but also the happiness of each of his powers in their realization of their perfection, which is their perfection. ${ }^{56}$

From Ibn Sīnā's point of view, a human being achieves happiness that both his theoretical intellect and his practical intellect reach perfection. The theoretical intellect of the rational human soul is perfected by understanding all forms of the universe, and it is the dignity of the human intellect to be aware of the whole universe from the first source to the intellects, the soul, tangible objects, and so on. But achieving this awareness and knowledge is obtained by illuminating and emitting light from the Tenth Intellect. ${ }^{575859}$

According to Ibn Sīnā, happiness is related to perfection and perfectionism is a natural thing that exists in every creature, but their levels of perfection are different from each other, and human perfection is in reaching God, which is the highest kind of perfection. Also, on the other hand, the subject of happiness is related to pleasure in such a way that happiness causes the vitality of the human soul, and this meaning exists only in intellectual pleasure.

Happiness is achieved through knowledge and awareness as stated by Ibn Sīnā. Man must first know the Creator and, as it should be, find his signs in the universe and know his own soul, and by acquiring this knowledge, make his way into the realm of certainty. After that, happiness will be achieved for him and the supreme happiness is that man should consider God in all matters and obey His commands and meet Him in the hereafter.

In Ibn Sīnā's statements about happiness, the desire for happiness should be crystallized in two things; both in terms of the soul and in terms of intellect. In terms

54 Ibn Sīnā, 'Uyūn Al-Hikmah (Beirut: Dār al-Qalam, 1980), 60.

55 Sīnā, Al-Ishārāt Wa Al-Tanbīhāt, 4:76.

56 Sīnā, 4:18.

57 Ibn Sīnā, Al-Mabda' Wa Al-Ma'Ād, ed. Abdullah Nourani (Tehran: McGill University Islamic Studies Publishing Institute and the University of Tehran, 1983), 103.

58 Ibn Sīnā, Aqsām Al- 'Ulūm (Cairo: Maṭba'ah Hindiyyah, 1908), 116, 118.

59 Ḥasan Ḥanafī, Min Al-Naql Ilā Al-Ibdā ', vol. 3 (Cairo: Dār Qubā' li al-Ṭibā'ah wa al-Nashr wa alTawzī‘, 2001), 630-31. 
of the soul, it is the case that a person should control the soul and adorn it with worship, and intellectually, it is to acquire knowledge and think in the world, know his God, and know the level of perfectionism by knowing him.

\section{D.1. Degrees of Happiness in Ibn Sīnā's Thought}

According to Ibn Sīnā, happiness has levels and is doubtful and has intensity and weakness, and also the factors that cause happiness are different. It is possible that at one time certain factors cause happiness and at another time, another factor. Can we say that happiness, in general, is relative? From one perspective, the answer to this question is positive and from another perspective is negative. If we consider happiness as defined by Ibn Sīnā, it may be considered to achieve sensory pleasures, and for another person who is at a higher level of perception, a higher degree of meaning is significant. On the other hand, because human beings are of the same type and have the same powers, instincts, and talents, they have the same happiness and the same perfections and charities make them happy.

Ibn Sīnā considers the highest level of happiness in that man is connected to the divine grace and is under the providence of God and the means between him and his beloved, who is the beloved of all beings, are removed and move towards him and settle down upon his arrival and his consistency becomes the love of the one who is the pure right and pure good and the lover of pleasure. ${ }^{60}$

According to Him, the highest level of happiness is for a person to consider himself under God Almighty's commands and overcome the inner and outer devil and enjoy divine grace. In some of his works, Ibn Sīnā considers the happiness of man in that the human soul becomes abstract from matter, that is, the whole soul that belongs to the body, although it is abstract in nature, participates with the body in action, which is a material thing until the stage of complete abstraction. ${ }^{61}$

In some of his works, Ibn Sīnā considers the highest degree of human happiness in the fact that man is theoretically elevated to the point where he can draw a correct and complete picture of the world outside his mind. Ibn Sīnā in his treatise al-Nafs has explained this better and more accurately than his other works. In this treatise, he states: "The human soul has several powers; one of these powers is the power of reason, and each of these powers has potential capacities that if these potential capacities become actual, then this power will reach its perfection and happiness". ${ }^{62}$ In his works, Ibn Sinnā has stated that the intellectual world becomes like the external world, similar to the active intellect and abstraction from matter as the ultimate happiness.

60 Sīnā, Treatise on Happiness, 275-76.

61 Sīnā, Al-Mabda’ Wa Al-Ma 'Ā' 119.

62 Einollah Khademi, “Happiness from Ibn Sina’s (Avicenna) Point of View," Philosophy of Religion 7, no. 5 (2010): 113-39, https://jpht.ut.ac.ir/article_22397.html?lang=en. 


\title{
D.2. Classification of Happiness from Ibn Sīnā's Point of View
}

In his works, Ibn Sīnā has expressed three categories of happiness, in each of which, certain characteristics and states are crystallized. This classification is:

First, Physical and Spiritual. Ibn Sīnā believes that just as we have physical and spiritual happiness, we also have physical and spiritual cruelty, and spiritual cruelty is specific to the souls of sinners, and in the shadow of this cruelty, they get the most severe pain. ${ }^{63}$

Although Ibn Sīnā considers drowning in bodily desires and immersion in the lower shore of human existence as a wrong thing and introduces such a vital state among the animals, he does not tolerate absolute disregard for the body and divides happiness into two types, physical (body) and spiritual (soul) and states: "Physical happiness is related to the body and is emphasized by religion, and God conveyed this kind of happiness in the language of the prophets, and they combined the two types of physical and spiritual happiness. In other words, the divine prophets believe that in addition to the soul, the body also continues its life by being resurrected because God is omnipotent and omnipotent in whatever He wills, and is also capable of revealing the body". ${ }^{64}$

Ibn Sīnā believes that man should not simply see his happiness in the hereafter and ignore the blessings that God has given him in this world because this is against the will of God and God has created all those blessings for human use. Therefore, it is necessary for us to achieve physical happiness and not deprive our souls of the blessings that God has bestowed upon them. Ibn Sinnā states that the divine sages desire to obtain the pleasures of spiritual happiness in relation to physical pleasures. It is as if they do not pay attention to physical happiness and do not know physical pleasures as anything other than spiritual happiness close to God. ${ }^{65} \mathrm{He}$ states:

\begin{abstract}
"We cannot act to prove the rebirth of the body and physical happiness through the intellect, but we must know it through revelation and religion, and the prophets have confirmed this news and they have emphatically conveyed the message to human beings that the human body will either suffer losses on the Day of Judgment or will have the status of a servant. Also, this matter has been mentioned in detail in the religion of Prophet Mohammad because the intellect confirms the prophethood of the Prophet. ${ }^{66}$
\end{abstract}

Second, Comparison with Different Powers of the Soul and Connection with the Soul Itself. If we consider happiness in terms of comparison with different powers of the soul, it can be analyzed as follows: The human soul has different powers and is considered actual for each power, and if that power reaches actuality, in fact, its

63 ISīnā, Al-Ishārāt Wa Al-Tanbīhāt, 3:27-30, 46.

64 Ainollah Khademi, "Analysis of Happiness According to Al-Farabi," Journal of Philosopical Theological Research 10, no. 2 (2009): 81-107, https://doi.org/10.22091/PFK.2008.226.

65 Ibn Sīnā, Al-Shifâ '(Qom: Library of the Grand Ayatollah Marashi al-Najafi, 1978), 423.

${ }^{66}$ Khademi, "Analysis of Happiness According to Al-Farabi," 121. 
perfection is realized and at this time it can be claimed that that power has achieved its happiness. But if we consider happiness in relation to the human soul itself, we will find that the happiness and perfection of the human soul are in being absolutely deprived of matter and the parts of matter and reaching the stage of complete abstraction, that is intellect. Since the human soul can be examined in two ways in terms of essence and in terms of belonging to the body, so there are different states of happiness for human beings with different credentials.

According to Ibn Sīnā, the human soul is composed of different powers, and in one case, it means that that power is perfected and reaches happiness, and the other case is that the set of forces that make up the soul reach happiness and provide the happiness of all forces.

Third, Absolute and Constrained. Ibn Sīnā about this kind of happiness states: "Absolute happiness and misery are not attainable in the world, that is, no one in the world is absolutely happy or absolutely angry because what God has given him is not satisfied except through reason, because everyone is the wisest people in his own eyes, and if this is the case it is true, so in the world, there is absolutely no cruelty, no happiness, no good and no evil."'67

According to Ibn Sīnā, man does not achieve complete happiness in the world, nor does he live in complete misery because a person may be prosperous in the world in every way, both materially and spiritually. Still, since he does not obey the divine commands, he will suffer eternal cruelty in the hereafter or a person is in a difficult situation in this world and does not have the necessary well-being and comfort. Also, since he is obedient to the divine commands and takes steps towards his satisfaction, he will achieve happiness in the hereafter.

\section{E. Comparison of the Thought of Happiness between al-Fārābī and Ibn Sīnā}

Achieving true happiness has always been the concern of the purposefulness of human life in different ages and man has always sought to achieve things that he considered happiness. Because people have different mental foundations and are subject to a particular system of thought, it has always led to different interpretations of happiness.

Happiness in the word is anti-cruelty and means good fortune, and blessed is one who has reached the position of divine satisfaction in the light of obeying the divine commands. In the minds of philosophers, especially Islamic philosophers, the subject of happiness is a subject for reflection and discussion, and each of the philosophers in their various works has discussed and commented on this case. Meanwhile, al-Fārābì and Ibn Sīnā, who are among the most influential Islamic philosophers and have influenced the thoughts of many philosophers after themselves, have special opinions in this regard, and at the same time their theories are based on divine themes and

67 Sīnā, Al-Shifā', 423. 
Qur'anic guidelines. Al-Fārābī believes that in order to achieve happiness, man must be adorned with knowledge and virtue. He has defined happiness as the evolution of the soul to a higher level that is beyond matter. Ibn Sinna has also expressed happiness as a total cessation of sensations and limiting the view to the glory of the Almighty God and His rational observation. He believes that in order to achieve happiness, a human must engage in inner enlightenment and acquire knowledge. Therefore, both philosophers have emphasized that true happiness is separate from material sensations and is something beyond matter that is achieved in the light of true insight and knowledge.

In defining happiness, al-Fārābì has paid attention to the nature of its intrinsic goodness and has defined happiness based on the end of pleasure, but unlike al-Fārābī, Ibn Sīnā has defined happiness based on the concept of desirability and end. The difference between this is that Ibn Sinna paid more attention to the nature of human perfectionism, but al-Fārābī considered happiness to be an absolute good that man is inherently seeking, and human intellect itself moves in that direction and confirms it.

Ibn Sīnā believes that in each era different factors may be effective in achieving happiness. In another era, those factors not only do not lead to happiness but also lead to cruelty but from al-Fārābì's point of view, the factors for achieving happiness lie in two things; one is the human soul that strives for virtue, and the other is the power of reason to acquire knowledge and reveal the truths of the universe. These two factors will never change and are fixed and stable so that eventually a person can achieve happiness by using them.

\section{F. Conclusion}

Both philosophers have considered true happiness and pleasures to be related to the spiritual dimension, which cannot be achieved except in the abode of the hereafter, and have mentioned physical pleasures below spiritual pleasures.

Ibn Sīnā and al-Fārābì both believe that happiness has a hierarchy and have expressed that the highest level, which is true happiness, is obedience to divine commands and overcoming the inner and outer demons. Ibn Sīnā mentions that three main components form happiness. First, the components of goodness and universal truth values (al-khayr). Secondly, the component of joy, al-farh (not pleasure), which is obtained when a person is able to carry out the above al-khayr well and perfectly. Then, thirdly, the component of inner peace and tranquility that gives birth to very deep happiness that becomes very personal and cannot be described in words

Al-Fārābī also expressed happiness in two categories, real and suspicious. Unlike Ibn Sīnā, he only mentioned this category and mentioned true happiness as reaching to God in the hereafter. He considers suspicious happiness as anything that is used to achieve true happiness and considers things such as wealth, dignity, position, etc., as suspicious happiness. In fact, the views of Ibn Sīnā and al-Fārābī on the axis of 
happiness and that they know true happiness in the hereafter and its division into physical and spiritual happiness and other related topics indicate another aspect of inspiration of these two philosophers from authentic Islamic sources.

\section{Bibliography}

Al-Fārābī, Abū Naṣr. Al-Millah Wa Al-Nușūṣ Al-Ukhrā. Beirut: Dār al-Mashriq, 2002.

—. Fușūl Muntazi 'Ah. Beirut: Dār al-Mashriq, 1993.

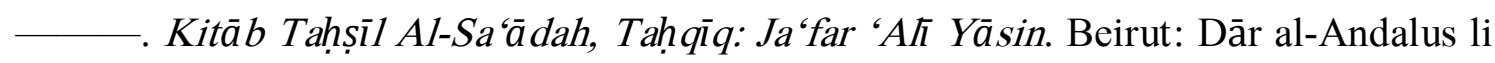
al-Tibā'ah wa al-Nashr wa al-Tawzī', 1983.

—. Risālat Al-Tanbīh 'alā Sabīl Al-Sa'Ādah. Edited by Subhāān Khalīfāt. Oman: al-Jāmi'ah al-Urduniyyah, 1987.

Al-Fārābī, Abū Naṣr, and 'Alī Būmalḥam. Al-Siyāsah Al-Madaniyyah. Beirut: Dār wa Maktabat al-Hilāl, 1996.

Al-Fārābī, Abū Nașr, and Seyed Jafar Sajjadi. Arā' Ahl Al-Madinnah Al-Fāḍilah. Tehran: Tahoori Publications, 1991.

Al-Ghazālī, Abū Ḥāmid. Iḥyā ’Ulūm Al-Dīn. Saudi Arabia: Dār al-Minhāj, 2013.

Kìmiyā Al-Sa'ādah. Miṣr: Maṭba'at al-Sa'ādah, 1924.

Al-Jawzīyah, Ibn al-Qayyim. Miftāh Dār Al-Sa'ādah Wa Manshūr Wilāyat Al-'Ilm Wa Al-Irādah. Jeddah: Majma’ al-Fiqh al-Islāmī, 2011.

Al-Kāshānī, 'Abd al-Razzāq. 'Abd Al-Razzāq Al-Kāshānī, Mu'jam Iṣtilāhāàt AlȘū fiyah, Taḥqùq: 'Abd Al-'Āl Shāhīn. Cairo: Dār al-Mannār, 1992.

Al-Mișrī, Jamāl al-Dīn Abī al-Faḍl Muḥammad b. Mukarram b. Manẓūr al-Anșārī al'Ifrīqī. Lisān Al- 'Arab. Vol. 3. Beirut: Dar al-Fikr, 1988.

Al-Muqrī, Aḥmad b. Muḥammad b. 'Alī al-Fayyūmì. Al-Misbāh Al-Munīr Fì Ghan̄b Al-Sharh Al-Kabìr. Vol. 1. Qom: al-Dar al-Hejrat Publications, 1988.

Al-Rāzī, Abū 'Abd Allah Muḥammad b. 'Umar b. al-Ḥasan b. al-Ḥusayn al-Taymī. Mafâtīh Al-Ghayb. Vol. 18. Beirut: Dār al-Fikr, 1975.

Al-Ṭabāțabā‘ī, Muḥammad Ḥusayn. Al-Mizān Fì Tafs̄ir Al-Qur'ān. Translated by Mohammad Baqer Mousavi Hamedani. Vol. 11. Tehran: Allameh Tabatabai Scientific and Intellectual Foundation (Golshan Press), 1988.

Al-Ṭūsī, Nașīr al-Dīn. Nasirean Ethics. Tehran: Islamic Theological Publications, 1987. 
Augustine, Aurelius. The Confessions of Saint Augustine. Translated by Edward Bouverie Pusey. London: Chatto \& Windows, 1921.

Bush, Stephen S. "Divine and Human Happiness in 'Nicomachean Ethics." The Philosophical Review 117, no. 1 (2008): 49-75. https://www.jstor.org/stable/41441846.

Cornell, Vincent J. "Applying the Lessons: Ideals versus Realities of Happiness from Medieval Islam to the "Founding Fathers"." Journal of Law and Religion 29, no. 1 (February 19, 2014): 92-108. https://doi.org/10.1017/jlr.2013.7.

Culp, Jonathan. "Who's Happy in Plato's Republic?" Polis 31, no. 2 (August 15, 2014): 288-312. https://doi.org/10.1163/20512996-12340018.

Farahidi, Khalil Ibn Ahmad. Al-'Ayn. Qom: Hijrat Publications, 1983.

Faris, Ahmad Ibn. Dictionary of Language Comparisons. Qom: Islamic Media Library, 1978.

Gurtler, Gary M. "The Activity of Happiness in Aristotle's Ethics." The Review of Metaphysics 56, no. 4 (2003): 801-34. https://www.jstor.org/stable/20131900.

Ḥanafī, Hasan. Min Al-Naql Ilā Al-Ibdā'. Vol. 3. Cairo: Dār Qubā' li al-Ṭibā'ah wa alNashr wa al-Tawzī‘, 2001.

Istifaiyah, Istifaiyah. “التّلّّق باخلاق الله عند عبد الكريم القشبيري." Teosofia: Indonesian Journal of Islamic Mysticism 4, no. 2 (October 16, 2015): 123-36. https://doi.org/10.21580/tos.v4i2.1719.

Jabbali, Said. "Happiness in the Thought of Al-Farabi: Theory and Practice." $\begin{array}{lllll}\text { Tabayyun } & 7, & \text { no. } & 25 & \text { (2018): }\end{array}$ https://tabayyun.dohainstitute.org/en/issue025/Pages/art04.aspx.

Khademi, Ainollah. "Analysis of Happiness According to Al-Farabi." Journal of Philosophical Theological Research 10, no. 2 (2009): 81-107. https://doi.org/10.22091/PFK.2008.226.

Khademi, Einollah. "Happiness from Ibn Sina's (Avicenna) Point of View.” Philosophy

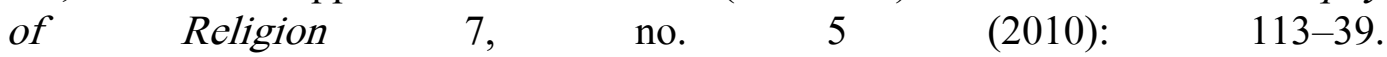
https://jpht.ut.ac.ir/article_22397.html?lang=en.

Klosko, George. "Socrates on Goods and Happiness." History of Philosophy Quarterly 3, no. 4 (1987): 251-64. https://www.jstor.org/stable/27743814.

Majidi, Hassan. "Happiness in The Thought of Farabi And S.T. Aquinas." Bi-Quarterly Journal of Political Science 9, no. 2 (2013): 95-114. https://doi.org/10.30497/pk.2014.1694.

McMahon, Darrin M. Happiness: A History. New York: Atlantic Monthly Press, 2007. 
Morteza, Shajari. "Happiness and Its Relationship with Knowledge and Worship from Ibn Sīnā's Point of View.” Journal of Philosophical Research 4, no. 8 (2010): 5991. https://www.sid.ir/en/journal/ViewPaper.aspx?id=389630.

Nasr, Seyyed Hossein. "Happiness and the Attainment of Happiness: An Islamic Perspective." Journal of Law and Religion 29, no. 1 (February 19, 2014): 76-91. https://doi.org/10.1017/jlr.2013.18.

Putri, Endrika Widdia. "Konsep Kebahagiaan Dalam Perspektif Al-Farabi." THAQAFIYYAT: Jurnal Bahasa, Peradaban Dan Informasi Islam 19, no. 1 (2018): 95-111. http://ejournal.uinsuka.ac.id/adab/thaqafiyyat/article/view/1321.

Rosenthal, Erwin Isak Jakob. Political Thought in Medieval Islam: An Introductory Outline. Cambridge: Cambridge University Press, 2009.

S.J., Joseph Rickaby. Joseph Rickaby S.J., Summa Contra Gentiles of Thomas Aquinas, Book 3. London: Burns and Oates, 1905.

Șadrā, Muhammad b. Ibrāhīm Mullā. Sharḥ Ușūl Al-Kāfi. Translated by Mohammad Khajavi. Tehran: Institute of Humanities and Cultural Studies, 2004.

Shamshiri, Mohammad Reza, and Zahra Allafchian. "A Comparative Study of 'Happiness' in View of Mulla Sadra and Spinoza." Biannual Scientific Journal

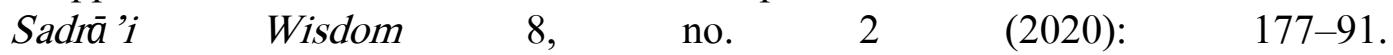
http://pms.journals.pnu.ac.ir/article_5013_en.html.

Sīnā, Ibn. 'Uyūn Al-Hikmah. Beirut: Dār al-Qalam, 1980.

Ah wāl Al-Nafs: Risālah Fi Al-Nafs Wa Baqā uhā Wa Ma'Āduhā. Beirut: Dār Iṇā' al-Kutub al-'Arabiyyah, 1952.

Al-Ishārāt Wa Al-Tanbīhāt. Edited by Sulaymān Dunyā. Vol. 3. Tehran: Book Publishing Office, 1977.

—. Al-Mabda' Wa Al-Ma'Ād. Edited by Abdullah Nourani. Tehran: McGill University Islamic Studies Publishing Institute and the University of Tehran, 1983.

—. Al-Shifã '. Qom: Library of the Grand Ayatollah Marashi al-Najafi, 1978.

_. Aqsām Al- 'Ulūm. Cairo: Mațba'ah Hindiyyah, 1908.

—. Treatise on Happiness. Qom: Bidar, 1974.

Vlastos, Gregory. "Happiness and Virtue in Socrates' Moral Theory." Proceedings of the Cambridge Philological Society 30 (February 28, 1984): 181-213. https://doi.org/10.1017/S0068673500004685. 
Wang, Stephen. "Aquinas on Human Happiness and the Natural Desire for God." New Blackfriars 88, no. 1015 (May 2007): 322-34. https://doi.org/10.1111/j.17412005.2006.00136.x.

Yaqoubi, Ibrahim. "Happiness from the Viewpoint of Ibn Sīnā and Allameh Tabatabai." University Scientific Quarterly 10, no. 1 (2007): 221.

Yāsin, Ja'far Āl. Al-Fārābì: Fi Hudūdih Wa Rusūmih. Beirut: Dār 'Ālam al-Kutub, 1985. 